\title{
〔19〕尿素樹脂の潜伏性硬化㓱としてのアミ， スルホン酸の触媒作用に関する研究
}

(1954 年 12 月 10 日受理)

秋田務* 長井登之雄*

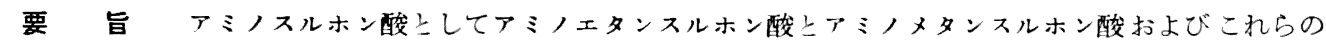
$\mathrm{N}$ ーアルキル置換体を合成し，尿素樹脂の潜伏性硬化剂乞しての性能を檢討した。これらのパルプ基材の尿素 樹脂成型材料に対方る硬化性指数を求为，さら江融点，水沪対寸る溶解度，ホルマリンによる $\mathrm{pH}$ の変化な

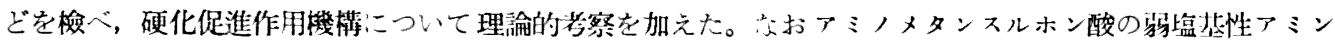
の笽がアミノメタンスルホン酸上りも硬化促進性が顯著であることを認めた。

\section{緒言}

尿素樹脂の硬化に際して工業的に使用される潜伏性硬化浏については從來幾多の化合物が踊告 されている゙。一方アミノスルホン酸は分子內にアミノ基とスルホン酸基とを其有し，これらは グリココールのようなアミノ酸と同樣に遊離の形で存在するよりもむしろ分子內塩をつくり，両 性イオンを形成していると考えられている2!。この両性イオンの形成によりその水溶液は比較的 中性に近い $\mathrm{pH}$ を示す性質があって，しかも成型溫度においては硬化促進性を発排することを発 見したので，潜伏性硬化珴として使用できはしないかと䒓えて研究を行った。

\section{実 驗 方 法}

1）硬化用：アミノェタンスルホン酸（以下 AES と略記する）の合成方汅については数多

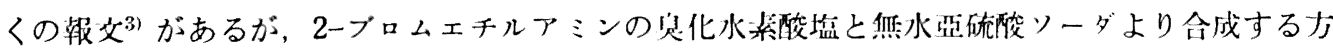

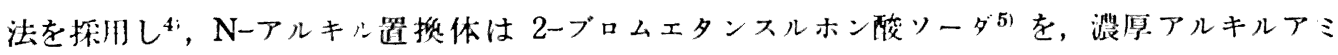
ン水溶液に溶し封渻中で加熱してつくった。Nートリメチルアミノェタンスルホン酸は AESを水

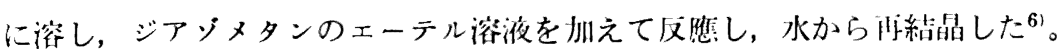

アミノメタンスルホン酸（以下 AMS と略記する）は伶却しながらホルムアルデヒドとアンモ

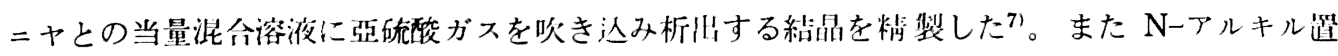
换体も同㥞の方法で相当するアルキルアミンを用い，析祮晶を水あるいはアルコールから再結 晶した。AMS または Nーメチルアミノメタンスルホン酸を適当甾の水, アルコール浙合溶液に

* 理矿合成澍脂株式全社（果京都中央区銀座 6) 
惩濁しこれれに計算量より過剩のアミンを加え透明になるまで煮沸した後, 析出する結晶を再結 晶してこれらの塩を得た。これらの絬晶の元素分析们は次のとおりであった。

\section{表 A}

\begin{tabular}{|c|c|c|c|c|c|c|c|}
\hline \multirow{2}{*}{\multicolumn{2}{|c|}{ 塩 }} & \multicolumn{2}{|c|}{$\mathrm{N} \%$} & \multicolumn{2}{|c|}{$\mathrm{C} \%$} & \multicolumn{2}{|c|}{$\mathrm{H} \%$} \\
\hline & & 計算值 & 実瞼値 & 計算値 & 実镮値 & 計算侹 & 実瞼值 \\
\hline アミノメタンスルホン酸 & ジェチルナミン塩* & 15.20 & 11.61 & \multirow{8}{*}{$\begin{array}{l}44.02 \\
44.02\end{array}$} & \multirow{8}{*}{$\begin{array}{l}43.91 \\
44.56\end{array}$} & \multirow{8}{*}{$\begin{array}{l}6.47 \\
6.47\end{array}$} & \multirow{8}{*}{$\begin{array}{l}6.43 \\
6.26\end{array}$} \\
\hline " & $ア=リ ン$ 笽 & 13.72 & 13.27 & & & & \\
\hline " & $o$-トルイジン壏 & 12.84 & 12.92 & & & & \\
\hline " & p-トルイジン塩 & 12.84 & 12.72 & & & & \\
\hline$"$ & a-ナフチルアミン塩 & 11.02 & 10.87 & & & & \\
\hline " & $\beta$-ナフチルテミン塩 & 11.02 & 10.75 & & & & \\
\hline$"$ & メラミン塩 & 41.33 & 43.60 & & & & \\
\hline \multicolumn{2}{|c|}{ N-メチルアミノメタンスルホン酸pートルイジン塩 } & 12.06 & 12.10 & & & & \\
\hline
\end{tabular}

・吸癷性强く、不安定なため失酜值は過小こでた。

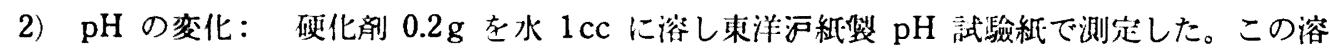

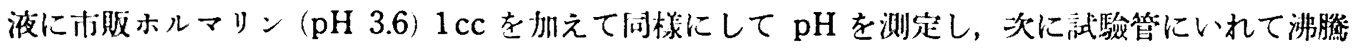
水中に 3 分間浸㳳した後室溫になるまで放冷して加熱後の $\mathrm{pH}$ を测定した。

3）成梨材料：尿素とホルマリンは才肘品をそのまま使用しモル此は $1: 1.5$ となるように 配台し， pH 7.4 となるまでへキサメチレンテトラミンを加え，溫度 $45^{\circ} \mathrm{C}$ で 2 特間加熱した。 この初期縮合物に液量の $25 \% 。$ の秎末状レーヨンパルプを加え, $105^{\circ} \mathrm{C}$ で乾燥した後ボールミル 中で枌碎して製造したものを基準成型材料とし，これに $0.2 \%$ の硬化肪を添加しボールミル中で さらに 5 洔間泚和した。

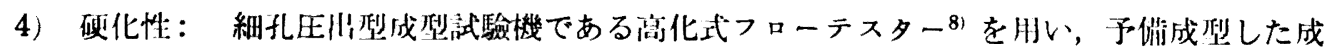
型材料 $1 \mathrm{~g}$ 在 $140^{\circ} \mathrm{C}$ に加就してあり，下部に孔径 $0.5 \mathrm{~mm}$ ，孔表 $1 \mathrm{~mm}$ のノッ゙ルがある本体中 にいれ，10 秒後にプランジャーで $200 \mathrm{~kg} / \mathrm{cm}^{2}$ の压力を㞦え，ハッ゙ルから押法される樹脂の流 H量を测り，硬化風の作州の䖪さを数守的に表現するために次式によって計算される硬化性指数 を求めた。

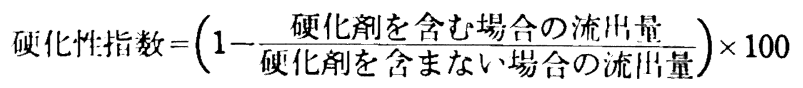

\section{実䵷結果および考察}

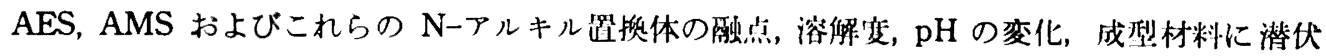
性硬化副として使用した場合の硬化性を第 1 尖に示した。 


\begin{tabular}{|c|c|c|c|c|c|c|c|c|c|c|}
\hline \multirow{2}{*}{ 硬 } & \multirow{2}{*}{ 化 } & \multirow{2}{*}{ 戍 } & \multirow{2}{*}{\multicolumn{2}{|c|}{$\begin{array}{c}\text { 骶 } \\
\left({ }^{\circ} \mathrm{C}\right)\end{array}$}} & \multicolumn{2}{|c|}{$\begin{array}{c}\text { 水に対する溶解度 } \\
(\%)\end{array}$} & \multirow{2}{*}{$\begin{array}{c}\text { 水溶液の } \\
\mathrm{pH} \\
24^{\circ} \mathrm{C}\end{array}$} & \multicolumn{2}{|c|}{$\begin{array}{c}\text { ホルマリン源加 } \\
\text { 時の } \mathrm{pH}\end{array}$} & \multirow{2}{*}{$\begin{array}{l}\text { 硬化性 } \\
\text { 指数 }\end{array}$} \\
\hline & & & & & $20^{\circ} \mathrm{C}$ & $60^{\circ} \mathrm{C}$ & & 值 後 & 加呹後 & \\
\hline \multicolumn{3}{|c|}{ アミノエタンスルホン酸（AES） } & 308 & 分解: & 8.9 & 23.5 & 5.8 & 3.6 & 3.4 & 71.5 \\
\hline N-メチル & " & & 242 & & 46.3 & 易 & 5.8 & 4.0 & 4.0 & 59.3 \\
\hline N-ジメチル & $"$ & & 301 & 分解 & 易 & 易 & 5.8 & 4.0 & 4.0 & 9.8 \\
\hline N-トリメチル & $"$ & & 314 & $"$ & 9.0 & 24.8 & 6.2 & 3.6 & 3.6 & 94.5 \\
\hline N-エチル & " & & 147 & & 易 & 易 & 5.8 & 4.0 & 4.0 & 3.2 \\
\hline N-ジェチル & $"$ & & 183 & & 易 & 易 & $\begin{array}{c}5.8 \\
20-30^{\circ}, 60^{\circ}\end{array}$ & 4.0 & 4.0 & -1.6 \\
\hline \multicolumn{3}{|c|}{ アミノメタンスルホン酸 (AMS) } & 183 & 分解 & 1.9 & 6.6 & $\begin{array}{l}99^{\circ}, 4.0,2.4 \\
<1.2\end{array}$ & 1.6 & $<1.2$ & 21.5 \\
\hline $\mathrm{N}$-メチル & " & & 168 & " & 13.7 & 34.2 & 3.0 & 2.2 & 3.6 & 87.7 \\
\hline N-ジメチル & $"$ & & 145 & " & 21.5 & 易 & 3.8 & 2.2 & 3.6 & 90.2 \\
\hline N-エチル & $"$ & & 152 & $"$ & 27.6 & 易 & 4.0 & 2.4 & 3.6 & 94.9 \\
\hline N-ジエチル & $"$ & & $125 \sim$ & $30 \prime \prime$ & 易 & 易 & 4.2 & 4.0 & 4.0 & 0.5 \\
\hline
\end{tabular}

AES 類は高溫で塎融もしくは熱分解し，水に対する溶解度は低溫では少なく密溫になると溶 け易くなる。一般に $\mathrm{pH}$ は中性に近く, 從ってこれらの化合物を硬化倣として使用した成型材料 は常溫安定性が良好である。Nートリメチルアミノェタンスルホン酸を除きアミノ基に対するア ルキル基の萁入は融点を低下し，水溶性を㙼加する倾问がある。また硬化促進性はアルキル基の 影響で弱くなり，N-ジェチル迕换体ではむしろ遅延する結果になったが，Nートリメチル置换体は 硬化促進性の点でもその傾向を逆轉し顯著な促進作用を有していることがわかった。結局その序 列は次のようになった。

$$
\begin{aligned}
& \left(\mathrm{CH}_{3}\right)_{3} \stackrel{+}{\mathrm{N}}->\mathrm{H}_{3} \stackrel{+}{\mathrm{N}}->\mathrm{CH}_{3} \stackrel{+}{\mathrm{N}} \mathrm{H}_{2}->\left(\mathrm{CH}_{3}\right)_{2} \stackrel{+}{\mathrm{N}} \mathrm{H}-> \\
& \mathrm{C}_{2} \mathrm{H}_{5} \stackrel{+}{\mathrm{N}} \mathrm{H}_{2}->\left(\mathrm{C}_{2} \mathrm{H}_{5}\right)_{2} \stackrel{+}{\mathrm{N}} \mathrm{H}-
\end{aligned}
$$

AMS 類の分解溫度は前孝に比べれば概して低く，中には成型溫度附近のものもあり，离溫にお ける水溶性を塯大することや，後述するアルキル基の影響などと相まって硬化促進作用を有利に しているものが多:。 $\mathrm{pH}$ は $\mathrm{N}$ にアルキル置捘が行われると，次第に上少するが一般に低く，ホ ルマリンの添加に上りその $\mathrm{pH}$ に影響されてさらに低下し，これを州熱すると檤に上外する傾向 がある。硬化促進性は AMS が AES よりも酸性に供っているにもかかわらすかかって弱いが， $\mathrm{N}$ ーアルキル置抝体のアルキル基の数または大きさを塯すに從い强くなる。すなわち $\mathrm{N}$-エチル置 掺体では管しい硬化促進性を示す。たたし N-ジェチル置挨体ではかえって微弱であり，その浊 さの順序は次のようになった。

$$
\mathrm{C}_{2} \mathrm{H}_{5} \stackrel{+}{\mathrm{N}} \mathrm{H}->\left(\mathrm{CH}_{3}\right)_{2} \stackrel{+}{\mathrm{N}} \mathrm{H}->\mathrm{CH}_{3} \stackrel{+}{\mathrm{N}} \mathrm{H}_{2}->\mathrm{H}_{3} \stackrel{+}{\mathrm{N}}->\left(\mathrm{C}_{2} \mathrm{H}_{5}\right)_{2} \stackrel{+}{\mathrm{N}} \mathrm{H}-
$$

以上のような結果を考察するために次のような実驗を行った。すなわち AES または AMSを 
ホルアリンと者沸したとこう $\mathrm{pH}$ の值を次第に娍少して, 粘秱な水溶性の治狀物質を生成し, こ のものを毞くときはメチルアミンの特臭を発生することを認めた。特に AMS については分仍

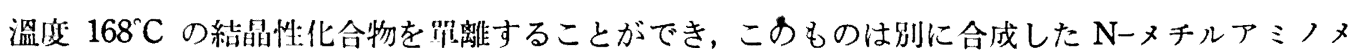

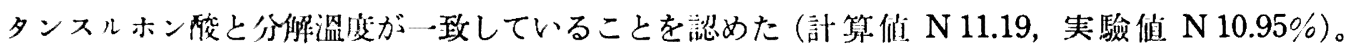
このことからアミノスルホン酸のアミノ昆も一般のアミノ基の場合と同じく，ホルムアルデヒド と作用してまホメチロール化命物を生じ，ついでおそらくメチレン化合物をつくり，さらに還元 されてメチル化する可能性をもっているものと䒓えることができる。從ってここに生ずるメチレ ンスルホン酸もしくは测生するギ酸により $\mathrm{pH}$ がさらに酸性によるため, 硬化作用が促進される ものと考えると,收もその可能性の大きい AMS の硬化促非性が最も强くなければならないはず であるが，実际はかえってその作用は低い程度に止ることは份述の通りである。從隶の瓜素樹脂

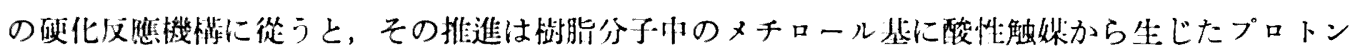
が作用してカルボ二ウムカチオンを生じ，これが求核性の $\mathrm{N}$ 原子に作川するためと考えられて いるが，アミノスルホン酸についてはこのような作川機蓝だけでは十分說明することができない ので次のように䒓えてみた。

すなわち, AES は水溶液の $\mathrm{pH}$ からみてもほとんど中州に近い狀態にあるから, 両性イオン

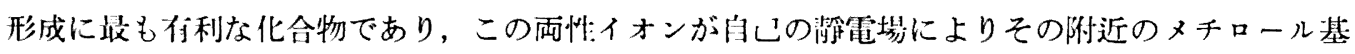
を動的感應効果によって次式のように分概させることにより活性化し，硬化作用の端緒を䦌くも のと考えてみた。

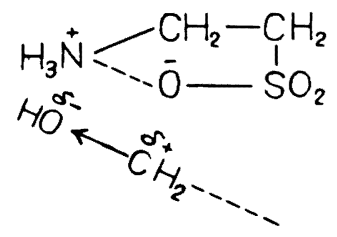

從って AES は大部分両性イオンになっているため,このアミノ酸にアルキル基を菜入するこ

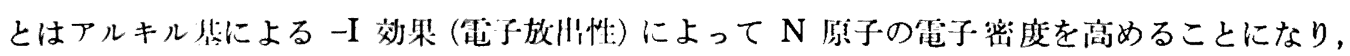
そのため分子の雭場の品さは弱められメチロール基の分做率を小さく止めるようになるので，前 述のように硬化作用が減少するのであると考えた。一方 $\mathrm{N}$-トリメチルアミノェタンスルホン酸

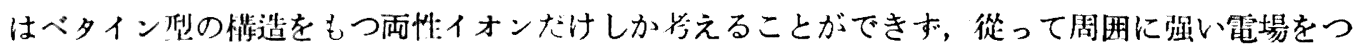
くる絬果硬化促非性が優れているのであると考えればこの化合物の特買性を說明することが できる。

AMS は AES に比べて pH の小さい点からわかるように両性イオンはやや不安定であって一 部酸電㷰を行いアニオンになっていると考えることができる。從ってアミノ基にアルキル基を䍃 入すればアルキル基の -I 効米により $\mathrm{N}$ 原子の電子密度を高め, プロトンを吸引する作用が强 
くなるので両性イオンの形成を有利にし，メチロール基の分極を起させ易くし，そのため縮合反 應を促進するのであると考えた。 $\mathrm{N}$-ジェチル置换体の硬化促進性が少るのは大きなアルキル基 による位置障害の効果によるためであると考えれば說明できる。ただし AMS は水溶性が歌め て少ないが，N-アルキル置換によって水溶性が塯し，熱分僻溫度が低下することも硬化性のよく なる一原因であると考えることもできるので，その作用機㮐を上述のような電子渝だけで說明す ることは行き過ぎであううが，少なくとも有力な一原因とは考えられると思う。次に AMS は弱 塩基性のアミンと水溶性の塩をつくることを知り，これらの塩を硬化促進剈として使用してみた

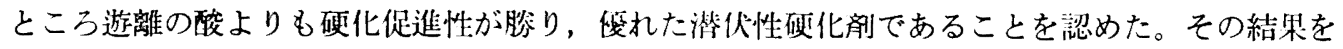
第 2 表に示す。

\begin{tabular}{|c|c|c|c|c|c|c|c|}
\hline \multirow{2}{*}{ 硬 } & \multirow{2}{*}{ 化 } & \multirow{2}{*}{$\begin{array}{c}\text { 融 } \\
\left({ }^{\circ} \mathrm{C}\right)\end{array}$} & \multirow{2}{*}{\begin{tabular}{|c|}
$\mid$ 水に対与士 \\
る溶解度 \\
$(0 \%)$ \\
$20^{\circ} \mathrm{C}$
\end{tabular}} & \multirow{2}{*}{$\begin{array}{c}\text { 水浴液 } \\
\sigma \mathrm{pH} \\
24^{\circ} \mathrm{C}\end{array}$} & \multicolumn{2}{|c|}{$\begin{array}{c}\text { ホルマリン浄加时 } \\
\text { の } \mathrm{pH}\end{array}$} & \multirow{2}{*}{$\begin{array}{l}\text { 硬化性 } \\
\text { 指数 }\end{array}$} \\
\hline & & & & & 直 後 & 加熱後 & \\
\hline アミノメタンスルホン酸 & 犮 ジェチルアミン塩 & 120 & 易 & 6.4 & 4.8 & 6.4 & 12.4 \\
\hline " & アニリン塩 & 176分解 & 23.6 & 6.2 & 2.6 & 3.0 & 92.2 \\
\hline$"$ & o-トルイジン塩 & $171 "$ & 13.1 & 5.4 & 2.4 & 2.8 & 97.9 \\
\hline " & p-トルイジン塩 & $181 " \prime$ & 5.5 & 6.2 & 2.2 & 2.6 & 93.1 \\
\hline$"$ & a-ナフチルアミン塩 & $183 " \prime$ & 2.7 & 6.2 & 4.0 & 3.6 & 90.2 \\
\hline$"$ & $\beta$-ナフチルアミン塩 & $183 \prime \prime$ & 2.2 & 6.2 & 4.0 & 3.2 & 89.3 \\
\hline " & メラミン塩 & $183 \prime$ & 0.7 & 4.6 & 4.4 & 3.0 & 81.4 \\
\hline \multicolumn{2}{|c|}{$\mathrm{N}-$ メチルアミノメタンスルホン酸 $p$-トルイジン塩 } & $165 \prime \prime$ & 10.9 & 6.2 & 4.0 & 4.8 & 92.6 \\
\hline
\end{tabular}

その理山として芳香族アミン中の $\mathrm{N}$ 原子はフェニール基の $+\mathrm{I}$ 效果（電子求引性）に基づいて 電子密度が低くなるために AMSのスルホン酸基についていたプロトンが酸分子中のアミノ基と

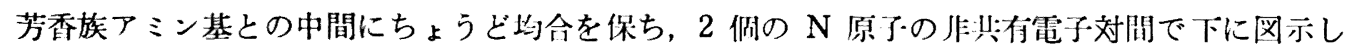
たように其鳴狀態のような形で安管化されると芌えると，

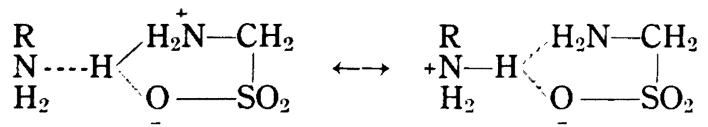

結局アミノスルホン酸の分子中の両性イオン榄造を妨げることなく芳否族アミンはこれと分子間 塩をつくることになり，その結果强い双極子電場をつくり，この箏電場が樹脂分子中のメチロー ル基に動的感憵勃果に基く分概を起させこれを活性化することになり，樹脂硬化作用の端緒を開 き著しい促進作用を示すものであると考えることができ，一應の說朋はつくようである。從って ジェチルアミンのような强塩基性のアミンでは $\mathrm{N}$ 原子のプロトン吸引忧が大きすぎて上記のよ うな造塩を行うことができないので一般の分子闍塩を形成し，両性イオンによる活性化作用は期 待できなくなるので硬化促進作用は微弱になるのであろう。 
しかし以上のような両性イオン榄造による硬化促進作用を確証するためには，上記のような潜

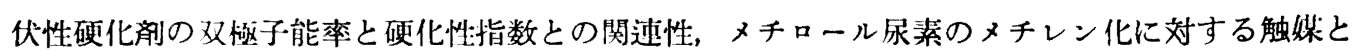
しての動力学的研究などさらに檢討を要すると思われれるが，一應考えられる以上の作用機構を 提案する。

附梩：本趣告注昭和 28 年 10 月 12 日, 合成樹脂工業協会, 高分子学会, 日本化学会共催, 熱硬化

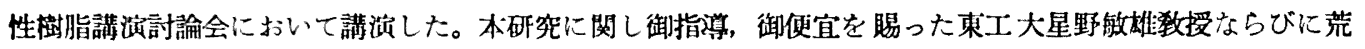
井定吉氏:こ厚く感謝致します。

\section{女䍊}

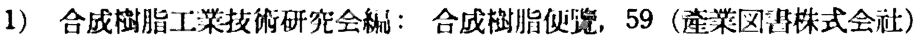

2) R. Kuhn and W. Brydówa: Ber., 70, 1333 (1937)

3) C.S. Marvel, C.F. Bailey and M.S. Sparberg : J. Am. Chem. Soc., 49, 1836(1927); F. Cortese: ibid. 58, 191 (1936) ; J.W. Schick and F. Degering: Ind. Eng. Chem., 39, 906 (1947)

4) Org. Syn. Coll., II, 804

5) ibid., 86

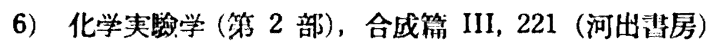

7) H.D. Hartough, J.W. Schick and J.J. Dickert: J. Am. Chem. Soc., 72, 1575 (1950)

8) 村井：日特第166642 号 ; 荒井, 桶田：高化, 6, 410 (1949)；星野等：昭和 26 年度交部省科学試喻 研究報告集鉃, 漹用化学篇, 123 (1952) 